\title{
Promoting economic diversification by the relationship between the minerals sector and transport infrastructure in Saudi Arabia
}

\author{
M. Aldagheiri \& M. Bradshaw \\ Department of Geography, University of Leicester, UK
}

\begin{abstract}
The macro-economy of Saudi Arabia has been dominated by oil exports which between 1970 and 1995 accounted for more than $85 \%$ of total export earnings. Due to the fact that oil is an exhaustible resource, the price of which fluctuates considerably, and is produced in an enclave economy, the Saudi Arabian government had recognized the need to diversify their economy away from oil as the main source of income. Since the oil price crash in 1986, the Saudi Arabian government has adopted a new policy to develop non-oil sectors, such as manufacturing, agriculture and, more recently, non-oil minerals. The reasoning behind the new Saudi Arabian policy can be summarized as follows. Firstly, large reserves of both metallic and non-metallic minerals such as gold, iron, copper and strategic minerals have been found such as, phosphate and bauxite. Secondly, it is believed that the minerals industry has relatively strong links with other sectors inside the country. Finally, minerals exports, as well as other nonoil commodities, could help in reducing the instability in exports and in turn reduce Saudi Arabia's total revenues fluctuation. As Saudi Arabia is a vast country, the government has therefore focused not only on locating mineral deposits, but also on making them accessible for exploitation. Saudi Arabia occupies over $70 \%$ of the Arabian Peninsula which encompasses a territory of about more than 2 million sq. $\mathrm{km}$. As a result, the issue of transportation infrastructure has been prominent on the government's agenda. The government's policies were advocated to better maintain, restore, rebuild, and invest in our highways, bridged, transit facilities, rail lines, airports, and ports. Therefore, the first aim of this paper is to evaluate the contribution of the non-oil minerals sector to the economic growth of Saudi Arabia during the period 1970-2005. The second aim is to identify and evaluate the role of the transportation infrastructure in the minerals sector.

Keywords: non-oil mineral resources, economic diversification, transportation infrastructure, highways, railways, ports, and Saudi Arabia.
\end{abstract}




\section{Background}

Saudi Arabia is a country of around 22 million people that occupies the greater part of the Arabian Peninsula. It differs from the majority of developing countries which generally have low per-capita income, high population to land ratios, a high proportion of agriculture in their GDP and high foreign debts. Saudi Arabia is well known as one of the major oil exporting countries in the world. Thus, the oil sector plays a crucial role in the economic activity of the country and the Saudi Arabian economy can be characterized as oil-dependent due to the high proportion of oil exports in the country's total exports and of the oil share in the overall GDP. Oil exports account for an average of $85 \%$ of total exports, while government revenues from oil varied between $70 \%$ to $90 \%$ on average between 1970-1995.

From the history of the Saudi economy, it can be seen that any decline in oil prices or in the country's production of oil could prove disastrous for the economy in terms of budget deficits Anderson [1], Nawwab et al. [2]. This uncertainty is due to the economy's heavy reliance on a single export commodity, oil. According to Alkhelaiwai [3], the oil windfall which accrued to the government in the aftermath of the Arab-embargo of oil in 1973 led the country to spend heavily in order to accelerate economic development. Similarly, the Saudi Arabian economy experienced an oil export boom during the 1970s and early 1980s due to an unexpected sharp increase in oil price and production, resulting, amongst other factors, from the Arab-Israeli war and the Iranian revolution. Therefore the national income rose and the balance of payments went into surplus. Such an outcome would normally have been considered a "blessing". The boom was followed by a gradual and then dramatic decline in oil revenues. This occurred particularly after the mid-1980s when Saudi Arabia stopped practising the role of a "swing producer" in OPEC in order to maintain the price of oil, as it had been adversely affected by OPEC members and independent oil producers increasing their quotas at the expense of the Saudi quota. Accordingly, the production of Saudi Arabia declined from five to less than three million barrels in the mid 1980s, and it might be expected that there would be consequences of this decline in oil price and production. Fluctuations in oil revenues over time may reflect and affect the Saudi Arabia small and open economy positively and/or negatively both through the oil export boom and the oil export slump. However, oil is a finite resource and reserves will eventually be exhausted or an alternative source of energy discovered. Moreover, fluctuation in oil prices mean the economy has faced a series of external shocks during the last two decades.

\section{Importance of the study}

In its commitment to diversify the economic base away from the oil sector, the Saudi Arabian government started to re-evaluate its policy with respect to diversification. In response to the fall in oil prices of 1982-83, Saudi Arabia realized the need to establish new policies that would increase the role of the 
non-oil sector in the economy. Throughout the Five-Year Development Plans (1970-2005), Saudi Arabian planners focused on economic diversification as a strategy to increase production in the non-oil sectors, such as manufacturing, agriculture and non-oil minerals in order to reduce dependency on oil exports as a major source of government income. Hence, the Saudi government established the state-owned Saudi Arabian Mining Company (Ma'aden), which will consolidate all mining projects in which the government is involved. This company is a 100 percent Saudi governmental holding company with an initial capital of more than $\$ 1$ billion. Therefore one of the government's aims has been to develop and promote the minerals sector in order to enhance its weak role in the Saudi Arabian economy, often by providing substantial incentives to develop the sector. The reasoning behind the new policy can be summarized as follows. Firstly, large reserves of both metallic and non-metallic minerals such as gold, iron, copper and clay have been found. Secondly, it is believed that the minerals industry has relatively strong links with other sectors inside the country. Finally, minerals exports, as well as other non-oil commodities, could help in reducing the instability in exports and in turn reduce Saudi Arabia's total revenues fluctuation.

As Saudi Arabia is a vast country, the government has therefore focused not only on locating mineral deposits, but also on making them accessible for exploitation. Saudi Arabia occupies over $70 \%$ of the Arabian Peninsula, a huge area which is larger than Western Europe and which encompasses a territory of about 2.25 million sq. km. As a result, the issue of transportation infrastructure has been prominent on the government's agenda. The government's policies were advocated to better maintain, restore, rebuild, and invest in our highways, bridges, transit facilities, rail lines, airports, and ports. For example, the minerals railway will run from Al-Jalamid in the far north of Saudi Arabia to Riyadh, where it will connect to an existing rail link to Dammam. According to Ministry of Planning (MOP) [4] a critical issue for most mining projects in remote areas is the extent to which the costs of the require infrastructure facilities include transportation are shared or allocated to the mining project alone. This affects the profitability of the mining projects considerably. Provision does exist for the Government to contribute to the costs of mining infrastructure. It is the Government's intention that this should have a major positive effect on the development of mining projects. In order to enhance the potential of the mineral sector a number of initiatives have been taken in the past couple of years. These initiatives as follow:

- $\quad$ it recommends solutions to infrastructure problems and methods for reducing mineral development costs;

- $\quad$ facilitates access by mineral exploration companies to geoscientific databases;

- $\quad$ simplifies and encourages investment in the mining sector; and

- $\quad$ establishes regulatory protocols to protect the environment and determine mining impacts on local communities Dew [5]. 
Therefore, to provide information about the ability of the existing transportation infrastructure to contribute to any exploitation of minerals, it is necessary to identify and evaluate the level of the existence of the transportation infrastructure in the Saudi Arabia.

\section{Literature review}

This section provides a review of the literature on the relationship between natural resource wealth and economic development. The major aim of this review is to examine the negative association between resource abundance and economic growth in recent decades, and additionally to explain the relationship between the road transport network and the minerals sector.

\subsection{The relationship between natural resources and economic development}

Based on Gylfason and Zoega [6] natural resources are considered an important source of national wealth around the world, but experience shows that natural riches are neither necessary nor sufficient for economic prosperity and progress. One of the late surprising features of economic life in the 20th century is that natural resource abundant economies tended to grow more slowly than economies without substantial resources Sachs and Warner [7]. For example, the Asian tigers,: Korea, Taiwan, Hong Kong and Singapore, are all resource-poor, while growth laggards such as Nigeria, Zambia, Sierra Leone, Angola, Saudi Arabia, and Venezuela, are all resource-rich. In the past there was also a negative association between resource abundance and growth. Typical examples include the Netherlands versus Spain in the seventeenth century, where resource-poor Netherlands eclipsed Spain despite the overflow of gold and silver from the Spanish colonies in the New World, and Switzerland and Japan who surged ahead of resource abundant economies such as Russia in the nineteenth and twentieth centuries Sachs and Warner [8], Stijns [9].

Stevens [10] stated that the problems associated with an influx of natural resource abundance were discussed in the 1950s and 1960s. However, he suggests that it was the oil crisis of the 1970s that led researchers to focus specifically on the impact of oil and mineral revenue. In general, a negative relationship between high natural resource intensity, namely a high value of resource-based exports to GDP, and the rate of growth appear as a robust empirical fact, with many examples showing resource-poor economies that outperform resource-rich economies in economic growth Aznar-Marquez and Ruiz-Tamarit [11]. Consequently the first use of the term 'resource curse' in the literature was Auty [12]. Auty examined the political economy of six countries and their macroeconomic responses to a series of external shocks. Auty's main aim was to investigate the suggestion that not only may resource-rich countries fail to benefit from a favourable endowment; they may actually perform worse than less well-endowed countries. In the next section, different theoretical contributions are examined that suggest explanations as to why natural resources might be a 'curse'. In addition, there are some examples from developing countries. 
Papyrakis and Gerlagh [13] conclude that resource riches such as oil reserves have not proved to be the panacea to underdevelopment. On the contrary, they have become associated with a slowdown in economic growth across the world during the last three decades. With a few exceptions, such as Botswana, Norway and Iceland, resource-abundant countries tend to belong to the list of development failures. One of the most striking manifestations of the resource curse hypothesis is the disappointing performance of the oil cartel countries. Gylfason [14] stated that the OPEC countries as a whole experienced a negative rate of GDP per capita growth in the last four decades. There are many modern analysts who consider that the advent of oil has led to economic deterioration, if not ruin, for "petrostates" Wright and Czelusta [15]. In Saudi Arabia the oil sector plays a crucial role in economic activity, and the Saudi Arabian economy can be characterized as an oil-dependent economy due to the high proportion of oil exports in the country's total exports, and also its high share in the overall GDP. Similarly, the Saudi Arabian economy experienced an oil export boom during the 1970s and early 1980s due to an unexpected sharp increase in oil price and production. This resulted in an expansion in the industrial sector, construction, infrastructure and transport, and several pipeline projects grew rapidly to facilitate the sale of oil. The negative macro-economic side-effects of the export boom are recognized in the economic literature as the 'Dutch disease phenomenon'. After the mid-1980s the boom was followed by a gradual and then dramatic decline in oil revenues. Accordingly, production in Saudi Arabia declined from five to less than three million barrels in the mid 1980s.

According to Gylfason [16] King Faisal of Saudi Arabia (1964-1975) would hardly have been surprised; he said (quoted from an interview with his oil minister, Shaikh Yamani), "In one generation we went from riding camels to riding Cadillacs. The way we are wasting money, I fear the next generation will be riding camels again". Saudi history has shown that any decline in oil prices or in the country's production of oil can prove disastrous for the economy in terms of budget deficits. This uncertainty is due to the economy's heavy reliance on a single export commodity, oil. With regard to the effect of a boom in one sector of the economy on the rest of the sectors, the oil sector boom in the 1970s in Saudi Arabia conforms very closely with the assumptions of the Dutch disease theory. Based on Al-Attas [17] the Saudi Arabian government has identified mining as an essential element in its programme to diversify the economy away from its present dependency on oil. The government's medium and long-term objectives for this sector include reaching out to private and foreign investors to establish industries for extracting and processing the minerals, and providing the Saudi manufacturing sector with its requirements in raw materials, as well as making Saudi Arabia a leading exporter of minerals.

\subsection{Transport sector and the minerals sector}

This section examines the relationship between transportation infrastructure and minerals sector with the aim of providing insights into how improving transportation infrastructure contributes in developing of economic activities (Figure 1). Based on Alfi and Zagan [18] minerals sector is the backbone of 
economy of many countries. Mining has always played an important role in the prosperity of nations. Gold, silver and other precious metals have been the focus of mining activities in past. This importance of minerals was recognized in the second half of the 19th century as the demand of the high-grade industrial raw materials was on rise. There are about 50 countries in the world in which mining sector plays an important role in the economy. Australia, Chile, Botswana, Peru, USA, Guinea, South Africa, Canada, Kazakhstan, Philippines, Papua New Guinea, China, Russia are the leaders in the global mining sector. In the industrialized countries such as Australia, United States of America, Canada, and Sweden, the mining is considering a vital sector to the economic development, where they largely depend on their natural resources for the development of their country. Also, Latin America is the leading region in today's global mining investment. For example, Chile is the most important country in Latin America, which has gain $46 \%$ of export revenues and $8 \%$ of GDP on average during 1990s.

On the other hand transportation is considered a subject matter of Economic Geography, which traditionally included Minerals, Agricultural and Industrial Geography. Goodall [19] stated that "the development of Economic Geography over the past three decades has witnessed the substitution of analysis for description, leading to an identification of the factors and an understanding of the process affecting the spatial differentiation of economic activities over the earth's surface". Transport has become an important subject matter for geographers for two main reasons. Firstly, transport is a significant human activity with a strong spatial component. Secondly, it is an important factor influencing the spatial variation of many other social and economic activities White and Senior [20]. Based on Mieczkowski [21] "the transport system may be likened to the blood circulation system in a living organism. Without it the organism dies". Transport is considered an essential feature of all modern economies. In general terms, as an economy grows and develops, it becomes more dependent upon its transport sector Robinson and Bamford [22].

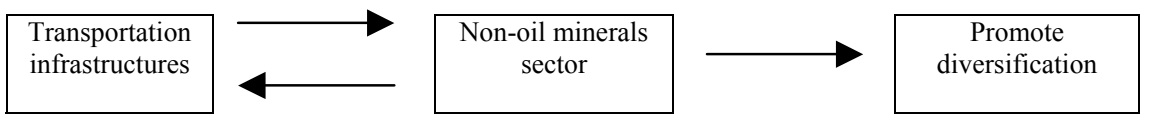

Figure 1: The relationship between transportation infrastructure and minerals sector.

The relationship between transportation infrastructure and economic development has been the focus of increasing analysis, discussion and interest during the past decade Weiss [23], Felloni et al. [24], Weiss and Figura [25]. The importance of transportation infrastructure to economic growth has been recognized for a long time. There is no doubt that investment in transportation systems (e.g. roads, ports and railways) stimulated economic development in North America in the 19th century. Roads and railroads allowed the United States to expand from states hugging the coast of the Atlantic Ocean to all the 
land between the Atlantic and Pacific Francois [26]. In addition, transportation infrastructure has expanded the range over which goods can be marketed. Although there is very little empirical evidence to this effect, it is generally believed that the U.S. government's massive investment in transportation infrastructure development in the 19th century led to the significant growth registered by the country's economy during that period Gillen [27]. In general, the previous efforts to explore the relationship between transportation infrastructure and economic development have been confined almost exclusively to developed countries and have typically dealt with one country at a time e.g., see Aschaeur [28], Evans and Karras [29], Garcia-Mila et al [30].

According to Ambe [31] the relationship between transportation infrastructure and economic development has always occupied a significant place in the development plans of less developed countries (LDCs). Furthermore the incorporation of transportation in the development plans of these countries dates back to the colonial era. The theoretical argument linking transportation infrastructure and economic development possesses both a logical and an intuitive appeal. This is particularly true in the case of developing countries, such as those of sub-Saharan Africa, where food preservation techniques are crude at best and nonexistent at worst, and where the need to move agricultural and other products from the farm to the market cannot be overemphasized. Thus the availability of dependable transportation facilities connecting rural and urban areas has positive economic implications. Baum and Tolbert [32] stated that Economic growth is impossible without adequate transport. Rural roads connecting isolated areas to markets and sources of supply are essential for converting agriculture from subsistence to a commercial activity.

In Sub-Saharan Africa there is an impressive array of projects underway in many parts of the region. Governments across the length and breadth of SubSaharan Africa are under unprecedented pressure to develop their road networks. According to Choudhury [33] the development of a better road network is a prerequisite to improve Africa's economic performance. With roads accounting for over 80 percent of all travel and freight movement, the development of a better road network is vital to boosting trade and for increasing access to rural areas. This was also expressed by Beimborn et al. [34] who postulated that with highways promoting economic growth by increasing access to new areas, this in turn may provide access to skilled labour markets and inexpensive land for starting new businesses. Accordingly the increasing accessibility of new areas will make them attractive for development.

Thus, it would seem that economic growth depends on the availability of infrastructure, and in particular on an efficient transport system. But in some areas, like the former communist countries of Eastern Europe, the rate at which these economies develop might be constrained by the poor state of transport. Because, the transport and logistics in general have received little attention Sanchez-Robles [35]. For example, Poland provides an interesting example of a country which used to have a centrally planned economy. Their industrial plans were based around heavy manufacturing and mining, and there was very little interest in transport. After more than 40 years of neglect, the country was left 
with an inefficient and badly organised transport industry, and an infrastructure which was in very poor condition. In 1989, the country moved to a free market economy. Also, the increase in trade and the rapid transfer of power in the supply chain from manufacturers to retailers put increasing demands on transport infrastructure. So, without considerable improvement, the defects of the network could make it increasingly difficult to move goods through the supply chain and the benefits of producing and selling in Poland would be offset by the costs of transport Waters [36].

Based on Lem [37] there are a substantial number of theories and empirical studies shed light on the relationship between economic development and transportation infrastructure, such as highways, distribution facilities and intermodal connectors. This affects four aspects of economic development:

$\begin{array}{ll}- & \text { Production costs } \\ \text { - } & \text { Industrial location } \\ \text { - } & \text { Regional productivity } \\ \text { - } & \text { Costs of inter-regional trade }\end{array}$

Generally highways affect most aspects of regional economic development because most economic activities either depend on or use highways in the transport of products. Moreover, highways affect regional productivity by connecting different regions to each other and allowing the exchange of goods and services to occur among them. For example, the highways of Louisiana and Indiana are considered a key component in business efficiency in the level and ease of access they provide to customers, markets, materials and workers. Additionally, they helped spur further growth in the states TRIP [38].

Also, sea and inland ports affect on economic development where, a lack of adequate port facilities can be a major deterrent to national and regional economic growth. Whilst the provision of modern port services may positively assist development by removing the inhibiting factor of low-level port facilities Hoyle and Hilling [39]. Also Lem stated that sea and inland ports give regions access to foreign trade and are usually a low-cost means for shipping bulky items to and from distant regions. These efficiencies impact productivity by enhancing the movement of large volumes of goods to distant regions and extending the market reach of industries and regions using the port facilities. In addition, the improvements in port services can increase a region's competitive advantage in attracting businesses from other regions. Like sea and inland ports, airports influence many important aspects of regional economic development and facilitate the fast delivery of important products and services.

Moreover, the transportation infrastructure impact is represented by the volume of movement between two places is in fact often in proportion to the quality, speed and cost of transportation facilities available. This relationship easily becomes circular, with improved facilities leading to increased volume of movement and the latter necessitating a further improvement in facilities Mabogunje [40]. Thus improved transport infrastructure can, for example, be defined as: 
(1) The reduction of travel time from a point of origin to a destination;

(2) The improved frequency of an existing and already used mode of transportation, for instance expressed in terms of numbers of services each hour;

(3) The increased access of a transportation system itself, e.g. provision of buses with greater capacity;

(4) The removal of a physical barrier, e.g. providing physical access to a location that was not accessible previously;

(5) The reduction of travel cost in the use of a transportation system between two points, whereby people have access to more widespread opportunities than before cited in Yeser [41].

In the Kingdom of Saudi Arabia, the position is similar to countries where transport infrastructure development is a prerequisite for economic development. Mining is a key element of the government's plans to diversify the economy under its Seventh five-year plan (2000-2005). In order to enhance the potential of minerals exploitation, the Saudi's government improved its transportation infrastructures. For example, the roads network represents a basic element of the transport system in the Kingdom where it plays a crucial role in facilitating the flow of traffic. The length of the road network, which satisfies high standards of safety, has expanded to 45.5 thousand kilometres in 1420 compared to only 8 thousand kilometres in 1390 . Nearly all towns and cities as well as most of the villages of the Kingdom are now linked by at least two-lane roads Al-Dagheiri [42].

Also, a detailed study on the railway project, which will link the Al-Jalamid and Al-Zabirah mining projects to the Gulf coast, has been drawn up and will be completed in the second half of 2005 by Canada's Canrail, Systra of France and Saudi Consolidated Engineering Services (Khatib and Alami). The railway will run from Al-Jalamid in the far north to Riyadh, where it will connect to an existing rail link to Dammam. In total, it will stretch more than 1,200 kilometres and pass close to the Al-Zabirah bauxite mine, which is situated near Hail, north of Riyadh MEED [43]. There are additional plans for a link between Al- Jubail and Ad Dammam on the Arabian Gulf, an east-west land bridge between Jeddah and Ad Dammam and a link to connect proposed mining sites with Al- Jubail, either via the capital Riyadh, or directly. The study's positive findings led to a recent review by the World Bank and the Saudi International Bank for possible financing of the cost of the railway which was estimated by SR 1.2 billion.

Regarding ports and shipping, the Kingdom has eight major ports with 183 berths capable of handling 252 million tonnes of cargo a year. The largest in terms of berths are Jeddah Islamic Port with 58 berths and Dmamm Port with 39. Total throughput of these eight ports in 2000, excluding erode oil, was 95.3 million tonnes. The volume of cargo handled at these ports reflects the level of development of the economic activity. The volume of cargo handled increased from 1.8 million weight tons in 1970 to 57.2 million weight tons in 1984 . However, this volume decreased to 52.1 million weight tons in 1985 and started to increase again in the following years to reach 88.5 million weight tons in 
1999. The substantial increase in the volume of cargo handled is due to industrial exports -via the industrial ports of Jubail and Yanbu - which increased to 56.5 million weight tons in 1999 MOP [44].

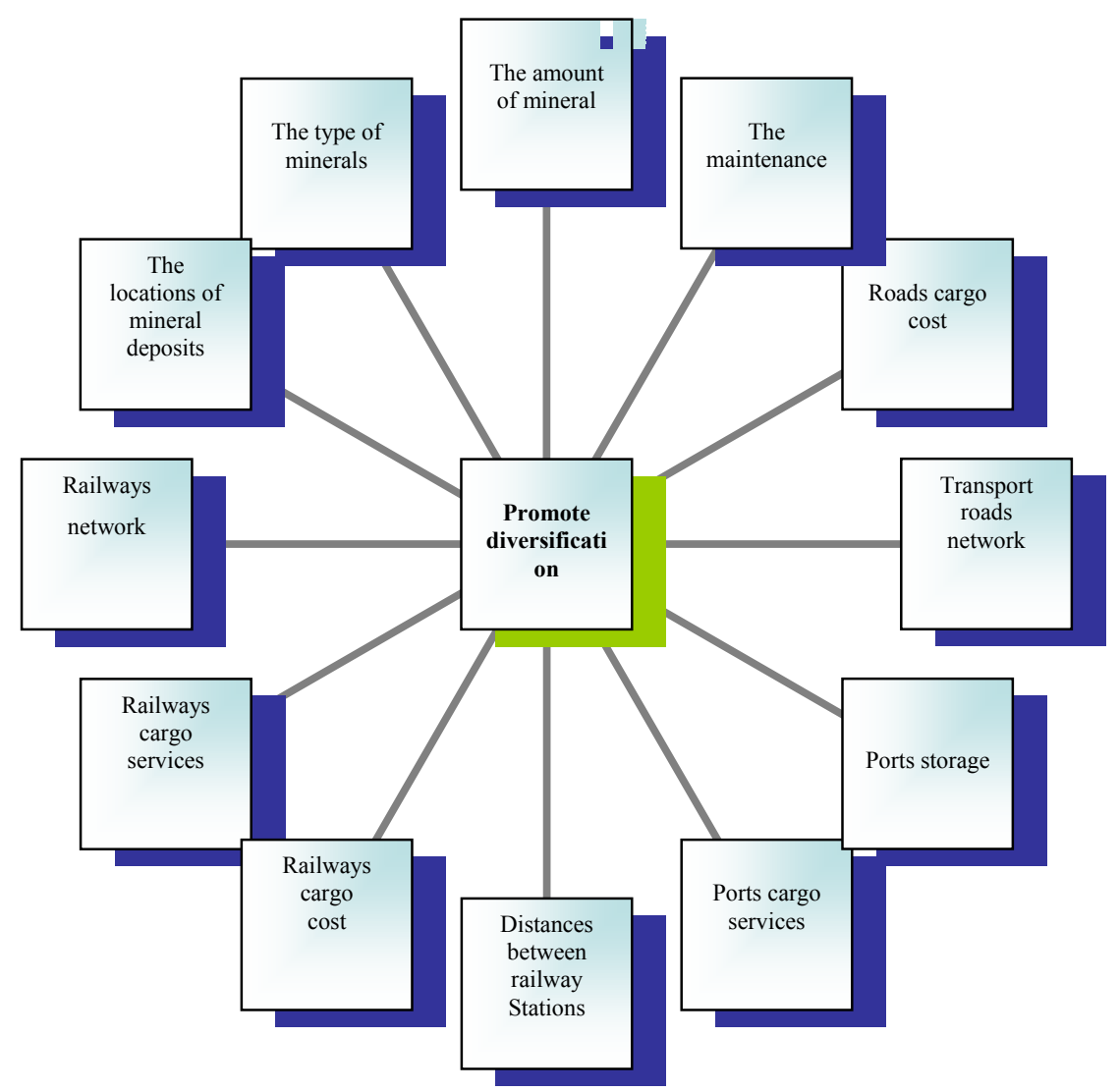

Figure 2: Conceptual model of the research variables.

\section{Methodology of the study}

The main goal of this part is to present a clear vision of the methods that will be used in this research. Mainly, this study intends to provide policymakers with specific recommendations regarding the promotion of economic diversification by the relationship between minerals sector and transportation infrastructure in Saudi Arabia. Nisbet [45] in an attempt to define a useful view to policy-making orientation suggested that "researchers undertake systematic procedures, such as surveys, to enable policymakers to base their decisions on evidence rather than on prejudice or guesswork". Saudi Arabia focused on economic diversification as a strategy to increase production in the non-oil sectors, such as non-oil 
minerals in order to reduce dependency on oil exports as a major source of government income. Also, the government focused on the transportation infrastructure as an important element to exploit the minerals resources. There are many methods which can be used to measure the relationship between minerals and transportation infrastructure, but convenient methods need to be developed to determine the reliability and validity of this relationship. Consequently, this research utilizes the survey to collect and analyze the relevant data. In addition, in this study, we use the descriptive approach to investigate the Saudi development strategy and highlight the main features and historical developments of the Saudi economy, the non-oil minerals sector and the transportation system.

\subsection{Variables of the research study and the need for data}

Twelve variables have been selected for the current research. These variables, which are defined below, are proposed as the factors that impact on the relationship between minerals and transportation infrastructure. They are presented through the conceptual model below.

\section{Conclusion}

Although the minerals play important roles in global economic development, however the role of the mineral sector in the economy of Saudi Arabia is insignificant where the oil sector is the driving force in economic activity. This paper investigated the role of minerals sector in the economic diversification away from oil as the main source of income through an establishing and improving the transport infrastructure. The minerals development heavily depends on transportation infrastructure. By facilitating minerals movement, transportation infrastructure can foster economic development. This paper presented three common types of transportation infrastructure improvements, and how they affect economic development.

\section{References}

[1] Anderson, I, Aramco, the U.S., and Saudi Arabia: A study of the Dynamics of Foreign Oil Policy, 1933-1950, Princeton: Princeton University Press, 1981.

[2] Nawwab, I, Speers, P, and Hoye, P, Saudi Aramco and Its World: Arabia and the Middle East, Dharan, Saudi Arabia: Saudi Aramco second edition, 1995.

[3] Alkhelaiwai, K, The impact of oil revenue fluctuations on the Saudi Arabian economy, PhD Thesis, University of Durham, 2001.

[4] MOP, Ministry of Planning, The Fourth Development Plan, Saudi Arabia, Riyadh: Ministry of Planning Press, 1985.

[5] Dew, P., Saudi Arabia: restructuring for growth, London, Euromoney, 2003. 
[6] Gylfason, T., Zoega, G., Natural Resources and Economic Growth: the role of investment, Working Papers, Central Bank of Chile, No 142, pp. 1-37, 2002.

[7] Sachs, J., Warner, A., Natural Resource Abundance and Economic Growth, National Bureau of Economic Research working paper, No 5398. pp. 1-49, 1995.

[8] Sachs, J.D. and A. M. Warner, Natural Resource Abundance and Economic Growth, Revised version, Center for International Development and Harvard Institute for International Development, pp. 1-28, 1997.

[9] Stijns, Jean-Philippe, Natural Resource Abundance and Economic Growth Revisited, Economics Working Paper Archive at Washington University, pp. 107-130, 2001.

[10] Stevens, P., Resource impact: curse or Blessing? a literature survey, The Journal of Energy Literature, 9, pp. 3-42, 2003.

[11] Aznar-Marquez and Ruiz-Tamarit, Renewable Natural Resources and Endogenous Growth, Discussion Paper at Department of Economic Analysis, Universitat de València (Spain), No. 2002029, pp. 1-21, 2002.

[12] Auty, R., Sustaining Development in Mineral Economies: The Resource Curse Thesis, Routledge, London and New York, 1993.

[13] Papyrakis, E., Gerlagh R., The resource curse hypothesis and its transmission channels, Journal of Comparative Economics, 32, 181-193, 2004.

[14] Gylfason, T., Nature, power and growth, Scottish Journal of Political Economy, 48, 558-588, 2001.

[15] Wright, G, and Czelusta, J., Mineral Resources and Economic Development. Conference on Sector Reform in Latin America, Stanford, pp. 1-29, 2003.

[16] Gylfason, T, Natural Resources, Education, and Economic Development, European Economic Review, 45, pp. 847-859, 2001.

[17] Al-Attas, A, The role of the non-oil minerals sector in the economic growth of Saudi Arabia, PhD. Thesis, University of Leeds, 2001.

[18] Alfi, K. and Zagan, A., The role of Mining Sector in the Diversification of Saudi Economy, Saudi Economic Survey, 38, pp. 48-56, 2004.

[19] Goodall, B., The Penguin dictionary of human geography, Penguin Books, Harmondsworth, 1987.

[20] White, H. and Senior, M., Transport geography, Longman, London, 1983.

[21] Mieczkowski, B., Transportation in Eastern Europe: empirical findings, East European Quarterly, Boulder, 1978.

[22] Robinson, H. and Bamford, C., Geography of transport, Macdonald \& Evans, Plymouth (Devon), 1978.

[23] Weiss, J, Infrastructure and Economic Development, Economic Research Papers, African Development Bank, 50, pp. 1-37, 1999.

[24] Felloni, F, Wahl, T, and Wandschneider, P., Evidence of the Effect of Infrastructure on Agricultural Production and Productivity: Implications for China, Chinese Agriculture and the WTO, Proceedings of WCC-101, Seattle, Washington, 1999. 
[25] Weiss, M. and Figura, P., A Provisional Typology of Highway Economic Development Projects, US DOT, Highway Administration: Washington DC, pp. 115-119, 2003.

[26] Francois, F., 21st Century Linkage Between Transportation and the Economy, Transportation Consultant: Transportation and Economic Development, Transportation Research Board (TRB) Committee on Transportation and Economic Development (A1A06), 2002.

[27] Gillen, D.W., Transportation infrastructure and economic development: A review of recent literature. Logistics and Transportation Review, 32, pp. 39-62, 1996.

[28] Aschaeur, D. A., Why is infrastructure important? In A. H. Munnell (Ed.) Is there a shortfall in public capital investment?, Boston: Federal Reserve Bank of Boston, pp. 21-50, 1990.

[29] Evans, P., and Karras, G., Is government capital productive? Evidence from a panel of seven countries. Journal of Macroeconomics, 16, pp. 271-279, 1994.

[30] Garcia-Mila, T., McGuire, J., and Porter, R., The effect of public capital in state-level production functions reconsidered. Review of Economics and Statistics, 78, pp.177-180, 1996.

[31] Ambe, N., Transportation Infrastructure and Economic Development in Sub-Saharan Africa, Public Works Management and Policy, 4, pp. 286-296, 2000.

[32] Baum, C., and Tolbert, S., Investing in development: Lessons of World Bank experience, Oxford, UK: Oxford University Press, 1985.

[33] Choudhury, R., Better roads vital for economic growth, (Sector Focus: Transport), African Business, 3, pp. 14, 1999.

[34] Beimborn, E., Horowitz, A., Vijayan, S., and Bordewin, M., An Overview: Land Use and Economic Development in Statewide Transportation Planning, Federal Highway Administration, pp. 1-99, 1999.

[35] Sanchez-Robles, B., The role of infrastructure investment in development: some macroeconomic considerations, International Journal of Transport Economics, 25, pp. 113-36, 1998.

[36] Waters, C., Changes to road transport in Poland during a period of economic transition, International Journal of Physical Distribution and Logistics Management, 29, pp. 122-138, 1999.

[37] Lem, L., Promoting Economic Development by Improving Transportation Infrastructure for Goods Movement, Reviews of Economic Development Literature and Practice, U.S. Economic Development Administration, 14, pp. 1-29, 2002.

[38] TRIP: The Road Information Program, The Road to Economic Development in Indiana: An Analysis of the Ability of Indiana's System of Highways, Roads and Bridges to Facilitate Economic Growth, A national transportation research group, Washington, D.C., pp. 1-27, 2005.

[39] Hoyle, B. and Hilling, D., Seaports and development in tropical Africa, London, Macmillan, 1970. 
[40] Mabogunje, A.L., The Development Process: A Spatial Perspective, Hutchinson University Library for Africa, 1980.

[41] Yeser, M., Transport and Development in the Yemen Arab Republic, PhD thesis, University of Wales, 1990.

[42] Al-Dagheiri, M., The Analysis of the Efficiency of Transport Road Network in the Al-Qassim Region, Saudi Arabia: A Geographical Study, MSc Dissertation, University of Leicester, 2004.

[43] MEED: Middle East Economic Digest, Maaden awaits decision on railway project, Defense Transportation Journal, 48, p21, 2004.

[44] MOP, Ministry of Planning, Achievement of the development plans, Riyadh: Ministry of Planning Press, 2000.

[45] Nisbet, J, Policy-oriented research in Johne P K eds Educational research methodology and measurement: an international handbook Elsevier Science Ltd, London, 1997. 